\title{
Front Matter: Volume 7188
}

, "Front Matter: Volume 7188," Proc. SPIE 7188, Nanoscale Imaging, Sensing, and Actuation for Biomedical Applications VI, 718801 (20 March 2009); doi: 10.1117/12.822784

SPIE. Event: SPIE BiOS, 2009, San Jose, California, United States 


\title{
PROGRESS IN BIOMEDICAL OPTICS AND IMAGING
}

Vol. 10, No. 28

\section{Nanoscale Imaging, Sensing, and Actuation for Biomedical Applications VI}

\author{
Alexander N. Cartwright \\ Dan V. Nicolau \\ Editors
}

27-28 January 2009

San Jose, California, United States

Sponsored and Published by

SPIE

Volume 7188

Proceedings of SPIE, 1605-7422, v. 7188

SPIE is an international society advancing an interdisciplinary approach to the science and application of light. 
The papers included in this volume were part of the technical conference cited on the cover and title page. Papers were selected and subject to review by the editors and conference program committee. Some conference presentations may not be available for publication. The papers published in these proceedings reflect the work and thoughts of the authors and are published herein as submitted. The publisher is not responsible for the validity of the information or for any outcomes resulting from reliance thereon.

Please use the following format to cite material from this book:

Author(s), "Title of Paper," in Nanoscale Imaging, Sensing, and Actuation for Biomedical Applications VI, edited by Alexander N. Cartwright, Dan V. Nicolau, Proceedings of SPIE Vol. 7188 (SPIE, Bellingham, WA, 2009) Article CID Number.

ISSN 1605-7422

ISBN 9780819474346

Published by

SPIE

P.O. Box 10, Bellingham, Washington 98227-0010 USA

Telephone +1 3606763290 (Pacific Time) · Fax +1 3606471445

SPIE.org

Copyright (C) 2009, Society of Photo-Optical Instrumentation Engineers.

Copying of material in this book for internal or personal use, or for the internal or personal use of specific clients, beyond the fair use provisions granted by the U.S. Copyright Law is authorized by SPIE subject to payment of copying fees. The Transactional Reporting Service base fee for this volume is $\$ 18.00$ per article (or portion thereof), which should be paid directly to the Copyright Clearance Center (CCC), 222 Rosewood Drive, Danvers, MA 01923. Payment may also be made electronically through CCC Online at copyright.com. Other copying for republication, resale, advertising or promotion, or any form of systematic or multiple reproduction of any material in this book is prohibited except with permission in writing from the publisher. The CCC fee code is 1605 $7422 / 09 / \$ 18.00$.

Printed in the United States of America.

Publication of record for individual papers is online in the SPIE Digital Library.

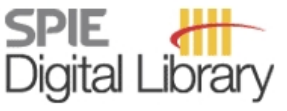

SPIEDigitallibrary.org

Paper Numbering: Proceedings of SPIE follow an e-First publication model, with papers published first online and then in print and on CD-ROM. Papers are published as they are submitted and meet publication criteria. A unique, consistent, permanent citation identifier (CID) number is assigned to each article at the time of the first publication. Utilization of CIDs allows articles to be fully citable as soon they are published online, and connects the same identifier to all online, print, and electronic versions of the publication. SPIE uses a six-digit CID article numbering system in which:

- The first four digits correspond to the SPIE volume number.

- The last two digits indicate publication order within the volume using a Base 36 numbering system employing both numerals and letters. These two-number sets start with 00, 01, 02, 03, 04, 05, 06, 07, 08, 09, 0A, OB ... 0Z, followed by 10-1Z, 20-2Z, etc.

The CID number appears on each page of the manuscript. The complete citation is used on the first page, and an abbreviated version on subsequent pages. Numbers in the index correspond to the last two digits of the six-digit CID number. 


\section{Contents}

$\checkmark \quad$ Conference Committee

\section{SESSION 1 NANOPHOTONICS FOR NANOMEDICINE}

718804 Biodetection of DNA and proteins using enhanced UV absorption by structuration of the chip surface (Invited Paper) [7188-03]

K. Robin, J. L. Reverchon, Thales Research and Technology (France); L. Mugherli,

M. Fromant, Ecole Polytechnique, CNRS (France); H. Benisty, Institut d'Optique (France)

\section{SESSION 2 BIOMOLECULAR RECOGNITION ELEMENTS}

718805 Brain machine interfaces combining microelectrode arrays with nanostructured optical biochemical sensors [7188-04]

M. Hajj-Hassan, T. Gonzalez, E. Ghafer-Zadeh, V. Chodavarapu, S. Musallam, M. Andrews, McGill Univ. (Canada)

718807 Intrinsic fluorescent recognition ligand scaffold based on chaperonins and water-soluble semiconductor quantum dots [7188-06]

H. Xie, B. I. Swanson, Los Alamos National Lab. (United States); H. K. Kawaga, J. D. Trent, NASA Ames Research Ctr. (United States); M. Kumara, T. Ippolito, M. Cotlet, Brookhaven National Lab. (United States)

718808 Thin-layer infrared spectroscopic study on thermal behavior of non-phospholipid lipids and nanovesicles [7188-07]

R. K. Bista, R. F. Bruch, Univ. of Nevada, Reno (United States); A. M. Covington, Univ. of Nevada, Reno (United States) and Nevada Terawatt Facility (United States)

718809 Near-infrared spectroscopic studies of self-forming lipids and nanovesicles [7188-08] R. K. Bista, R. F. Bruch, Univ. of Nevada, Reno (United States)

\section{SESSION 3 NANOPHOTONIC SENSORS I}

$7188 \mathrm{OB}$ Label-free biosensing using a photonic crystal structure in a total-internal-reflection geometry [7188-10]

Y. Guo, J. Y. Ye, C. Divin, T. P. Thomas, A. Myc, T. F. Bersano-Begey, J. R. Baker, Jr., T. B. Norris, Univ. of Michigan (United States) 
$7188 \mathrm{OE} \quad$ Enabling intelligent readout of luminescent signals from nanoscale biochemical sensors (Invited Paper) [7188-13]

L. Yao, McGill Univ. (Canada); K. Y. Yung, V. Tripathi, Univ. at Buffalo (United States);

V. Chodavarapu, McGill Univ. (Canada); A. Cartwright, F. Bright, Univ. at Buffalo (United States)

$7188 \mathrm{OF} \quad$ Synthesis, characterization and biosensing application of photon upconverting nanoparticles [7188-15]

M. Kumar, P. Zhang, New Mexico Institute of Mining and Technology (United States)

7188 OG Modelling the response of whispering-gallery-mode optical resonators for biosensing applications [7188-16]

W. Langbein, L. Chantada, N. I. Nikolaev, A. Ivanov, P. Borri, Cardiff Univ. (United Kingdom)

\section{SESSION $5 \quad$ NANOIMAGING WITH NANOPARTICLES}

7188 Ol Chemical nanoscopy of cell-like membranes (Invited Paper) [7188-18]

E. Bründermann, I. Kopf, M. Havenith, Ruhr-Univ. Bochum (Germany)

$7188 \mathrm{OL}$ Detection of nanoparticles accumulation in biological tissues by optical coherence tomography in vivo [7188-22]

M. A. Sirotkina, E. V. Zagaynova, Nizhny Novgorod State Medical Academy (Russian Federation); M. V. Shirmanova, Nizhny Novgorod State Medical Academy (Russian Federation) and N.I. Lobachevsky State Univ. of Nizhny Novgorod (Russian Federation); P. A. Agrba, V. A. Kamensky, Institute of Applied Physics (Russian Federation)

$71880 \mathrm{M}$ Circulation time estimates of optically active nanoparticles using a pulse photometer [7188-23]

G. J. Michalak, Louisiana Tech Univ. (United States); J. A. Schwartz, Nanospectra Biosciences, Inc. (United States); D. P. O'Neal, Lovisiana Tech Univ. (United States)

\section{SESSION 6 IMAGING}

$718800 \quad$ Probing mass-transport and binding inhomogeneity in macromolecular interactions by molecular interferometric imaging [7188-25]

M. Zhao, X. Wang, D. Nolte, Purdue Univ. (United States)

7188 OP Patterning of fibronectin using laser writer for force measurement in cells [7188-26]

B. Codan, T. Gaiotto, Univ. degli Studi di Trieste (Italy); R. Di Niro, Univ. of Oslo (Norway);

R. Marzari, V. Sergo, Univ. degli Studi di Trieste (Italy)

$7188 \mathrm{OQ}$ Self-assembly of biomolecules: AFM study of F-actin on unstructured and nanostructured surfaces [7188-34]

M. Naldi, Univ. di Bologna (Italy); E. Vasina, S. Dobroiu, L. Paraoan, D. V. Nicolau, Liverpool Univ. (United Kingdom); V. Andrisano, Univ. di Bologna (Italy)

Author Index 


\title{
Conference Committee
}

\author{
Symposium Chairs \\ James G. Fujimoto, Massachusetts Institute of Technology (United \\ States) \\ R. Rox Anderson, Wellman Center for Photomedicine, Massachusetts \\ General Hospital, and Harvard School of Medicine (United States)
}

Program Track Chairs

Paras N. Prasad, University at Buffalo (United States)

Dan V. Nicolau, The University of Liverpool (United Kingdom)

Conference Chairs

Alexander N. Cartwright, University at Buffalo (United States)

Dan V. Nicolau, The University of Liverpool (United Kingdom)

\section{Program Committee}

Igal Brener, Sandia National Laboratories (United States)

Philippe M. Fauchet, University of Rochester (United States)

Paul L. Gourley, Sandia National Laboratories (United States)

Piotr Grodzinski, National Cancer Institute (United States)

Brian McGraith, Dublin City University (Ireland)

Igor L. Medintz, Naval Research Laboratory (United States)

Ammasi Periasamy, University of Virginia (United States)

Paras N. Prasad, University at Buffalo (United States)

Weihong Tan, University of Florida (United States)

\section{Session Chairs}

1 Nanophotonics for Nanomedicine

Dan V. Nicolau, The University of Liverpool (United Kingdom)

2 Biomolecular Recognition Elements

Alexander N. Cartwright, University at Buffalo (United States)

3 Nanophotonic Sensors I

Alexander N. Cartwright, University at Buffalo (United States)

4 Nanophotonic Sensors II

Sharon M. Weiss, Vanderbilt University (United States) 
$5 \quad$ Nanoimaging with Nanoparticles

Vamsy P. Chodavarapu, McGill University (Canada)

$6 \quad$ Imaging

Vamsy P. Chodavarapu, McGill University (Canada) 